\title{
Utilisation of wastes as fertilisers with particular emphasis on the Bay of Plenty region
}

\author{
M.B. O'CONNOR1, A.H.C. ROBERTS1, R.D. LONGHURST1 and M.FHAWKE ${ }^{2}$ \\ ${ }^{1}$ Ruakura Agricultural Centre. Private Bag, Hamilton \\ ${ }^{2}$ MAF Technology, Rotorua
}

\begin{abstract}
Estimates of the wastes produced in the Bay of Plenty region indicate that 22 million $\mathrm{m}^{3}$ (tonnes) is produced annually. The main contributors to waste production are the dairy industry (shed, factory),municipalsewage,pig,poultry, meatworks, kiwifruit, fishing and pulp and paper industries. In fertiliser terms these wastes are valued at \$7.7 million. In addition the timber industry produces $>$ 1 million tonnes of timber residues (sawdust, bark, woodchips) approximately $20 \%$ of which is currently dumped. Wastes, when recycled back on to the land, offer a potential source of nutrients to enhance pasture and crop production. In addition organic wastes provide a source of organic matter which may have beneficial effects on the physical properties of soils.
\end{abstract}

Research results indicate that pumice soils are well suited to the application of wastes. Some general recommendations are given for the use of wastes in dairying, orcharding and cropping situations. Three factors are considered important for the successful utilisation of wastes (a) application rates need to be balanced to the nutrient needs of the soil-plant system (b) safeguards in the form of regular chemical monitoring of the effluent, soil, plant and animal need to be implemented, and(c) the economics of using the waste materials must be favourable to the farmer and orchardist. The principle of the producer of the waste paying for its safe disposal or utilisation needs to be adopted in New Zealand as it has in many overseas countries.

Keywords nutrients, organic matter, waste recycling, pumice soils, fertiliser value

\section{Introduction}

European farmers have traditionally cycled large quantities of animal and human wastes back onto the land. In the more intensively farmed countries like the $\mathrm{N}$ etherlands increasing quantities of wastes together with inputs of $400 \mathrm{~kg}$ per hectare or more of $\mathrm{N}$ fertiliser has put pressure on the environment (nitrate in water, ammonia volatilisation), so much so that strict legislation on the quantities of wastes to be returned to the land are being enforced (Mason 1991)

N ew Zealand farmers, on the other hand, because of all-year-round outdoor grazing have not been concerned with accumulations of animal manures nor has there been pressure to recyde wastes back on to the land. But increasingly in New Zealand there are environmental concerns particularly in relation to water quality and the need to keep wastes out of our waterways. In recent years there has also been a major downturn in fertiliser use on farms (MWBES 1991). Waste materials recycled back onto the land could be of assistance in both these areas. Hence we need to be in a position to critically assess (a) the range of waste materials available (b) their value in fertiliser terms for pasture and crop production and (c) any harmful components and possible long-term detrimental effects of using wastes. This paper will address these issues with particular emphasis on waste materials available in the Bay of Plenty region.

\section{Types of wastes, quantities and fertiliser value}

The wastes produced in the BOP region have been estimated (Table 1). The main contributors to waste production are the dairy industry (dairy shed, dairy factory) municipal sewage wastes and poultry and pig industries. Others includingmeatworks, kiwifruit, fishing and pulp and paper industries are also important contributors. In total 22 million $\mathrm{m}^{3}$ (tonnes) of waste materials is produced annually (excluding forestry), all of which could be considered a potential nutrient source to enhance pasture and crop production. Considered in fertiliser terms some 6580 tonnes of urea, 14900 tonnes of superphosphate and 4320 tonnes of muriate of potash is produced annually in the BOP region. Together this is valued at $\$ 7.7$ million. Relative to the sales of BOP Fertiliser Company on a proportional basis for the BOP region ( $\mathrm{R}$. Clark pers. comm.) this amounts to approximately $92 \%$ of the urea sold, $25 \%$ of the super-phosphate and $34 \%$ of the muriate of potash. These are not trivial amounts. 
Table 1 Estimates of the waste materials available in the Bay of Plenty.

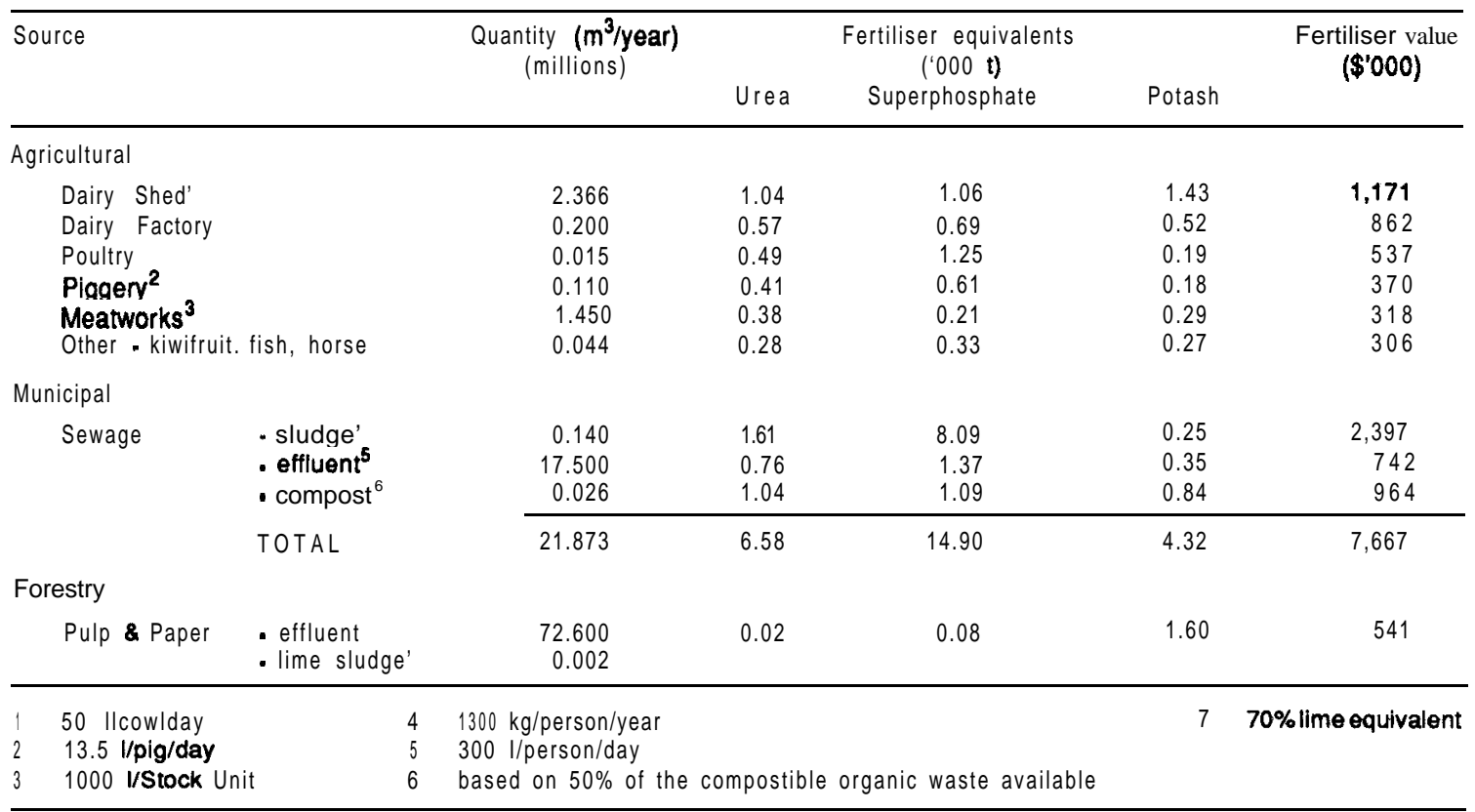

Table 2 Timber residues in the Bay of Plenty region'

\begin{tabular}{lcr}
\hline Product & $\begin{array}{c}\text { Annual production } \\
(\mathbf{t})\end{array}$ & $\begin{array}{r}\text { Quantity } \\
(\mathbf{t})\end{array}$ \\
\hline Sawdumst & 240,000 & 120.000 \\
Woodchips & 640,000 & $\mathrm{Nil}$ \\
Bark & 175.000 & 60,000 \\
Fibrous waste & 16,000 & 18,000 \\
(Pulp \& Paper) & & \\
\hline
\end{tabular}

from van Wyke (1990) and pers. comm.

The timber industry is a large supplier of waste particularly in the form of sawdust, woodchips and bark (Table 2). Although significant use is being made of some of these products, e.g. woodchips. large quantities of the others are currently dumped. Such products would be useful as sources of organic matter for composts made from a range of waste materials.

\section{Research results with wastes in the $\mathrm{BOP}$}

\section{Whey}

Two trials in the Reporoaregion between 1987 and 1989 compared whey with solid fertiliser. Treatments included whey at 45000 litres/ha and solid fertiliser applied at equivalent $\mathrm{P}$ and $\mathrm{K}$ levels to that in whey. A basal $\mathrm{S}$ application was made to all the solid fertiliser plots. Trials were on ryegrass-white clover pastures under dairy grazing with measurement by pasture probe on a beforeandaftergrazing basis (pers. comm.B.Thorrold). Results for the final 12 month period of the 3 year trial are shown in Table 3. Whey gave a similar yield to solid fertiliser at the Reporoa site and although slightly higher at the Whenuaroa site this difference was non-significant. The presence of $\mathrm{N}$ in the whey inevitably provides a short-term benefit to that treatment. Overall, whey provided an excellent substitute for potassic superphosphate. Soil and herbage chemical analyses (data not presented) over the 3-year period supported this view. No problems with soil wetness or surface soil stability were evident.

Table 3 Pasture production (kg DM/ha) for whey and solid fertiliser at 2 sites $-1989 / 90^{\prime}$

\begin{tabular}{lcr}
\hline & Whenuaroa & Reporoa \\
& & $(\mathrm{kg} \mathrm{DM} / \mathrm{ha})$ \\
\hline Control & 5,000 & 5,100 \\
Whey $(45,000 \mathrm{M} / \mathrm{ha})$ & 6,200 & 5,700 \\
Solid fertiliser (NPK) ${ }^{2}$ & 5,600 & 5,700 \\
LSD (5\%) & 1,010 & 680 \\
\hline Pasture production underestimated & \\
$2 \quad$ Equivalent to the PK In whey & \\
\hline
\end{tabular}


Sewage effluent

Effluent discharge onto land can be viewed both as a means of treating effluent and obtaining increased production from that land. Pumice soils are highly regarded in their ability to treat effluent (Childs et al. 1977). Experiments conducted in the late 1970s at the MAF Wairakei Research Station on a free-draining Atiamuri sand indicated the importance of selecting the correct plant species for effluent irrigation. Lucerne (Medicago sativa) treated with $85 \mathrm{~mm}$ effluent on a fortnightly basis gave an annual yield increase of $11 \%$ due to both an irrigation and anutrient effect $\left(\mathrm{O}^{\prime} \mathrm{Connor}\right.$ 1979). However, lack of winter growth resulted in poor $\mathrm{N}$ removal (average 47\%) resulting in increased nitrate levels in drainage waters (Stevenson \& Wilcock 1979). Subsequent work (O'Connor 198 1; Stevenson\&Fellows 1984) suggested tall fescue (Festuca arundinacea) was superior to Nui ryegrass (Lolium perenne) and prairie grass (Bromus cartharticus) in both production and $\mathrm{N}$ removal particularly in the second year(Table 4). Marked production increases were observed due to both an irrigation and nutrient effect. For example, the NPK applied at the effluent application rate of $85 \mathrm{~mm}$ every fortnight was 480,98 and $26 \mathrm{~kg} / \mathrm{hal}$ annum respectively.

Table 4 Pasture production (kg DM/ha/annum) and recovery for 3 pasture species with and without secondary treated sewage effluent'

\begin{tabular}{lccccccc}
\hline & \multicolumn{3}{c}{$1978-79$} & & \multicolumn{3}{c}{$1979-80$} \\
& No. Eff. & Elf. & $\begin{array}{c}\% N \\
\text { removal }\end{array}$ & No. Elf. & Eff. $\%$ & $\begin{array}{c}\mathrm{N} \\
\text { removal }\end{array}$ \\
\hline Tall Fescue & 3980 & 13,410 & 76 & 4530 & 16,330 & 91 \\
Nui ryegrass & 3210 & 11,490 & 40 & 2070 & 12,250 & 60 \\
Prairie grass & 4720 & 10.310 & 51 & 3900 & 12,200 & 67 \\
\hline
\end{tabular}

from Taupo Municipal Sewage

Pumice soils, then. are seen as being ideal for sewage effluent treatment. The additional pasture production with effluent could be utilised in situ by grazing animals using appropriate withholding periods (Collins 1984). be cut and carried to feeding lots. or be made into hay or silage. The last two options provide the best in terms of $\mathrm{N}$ removal from the effluent. Utilisation of sewage effluent in forests is another option currently being practiced in the region (Rotorua District Council 1991),

\section{Pulp and paper effluent}

Trials conducted in conjunction with the Tasman Pulp and Paper Company at Kawerau indicated that effluent application to pasture at rates up to $80 \mathrm{~mm} /$ week was beneficial topasturegrowthparticularlyoverthesummer period (Figure 1). This effect was considered mainly an irrigation effect as the effluent is low in $\mathrm{N}$ and $\mathrm{P}$ (Table 1). Associated soil and herbage chemical analyses (data not presented) indicated marked increases in $\mathrm{K}, \mathbf{S}, \mathbf{M g}$ and $\mathrm{Na}$ supporting the contention that pumice soils and vigorous pasture growth are excellent at 'stripping' nutrients from effluents. However, possible long-term detrimental effects such as increased soil $\mathrm{pH}$ and $\mathrm{Na}$ saturation would need careful monitoring with such a waste material.

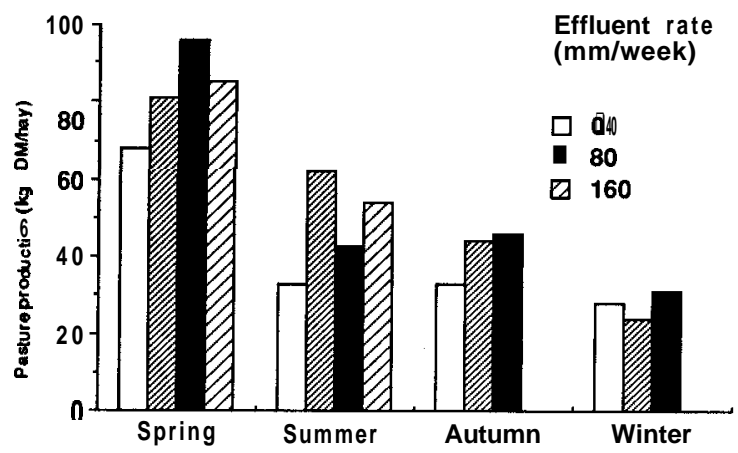

Figure 1 Pasture. production (kg DM/ha/day) in 1987/88 to various rates of pulp and paper effluent (data supplied by Tasman Pulp and Paper Company, Kawerau). Note: high rate $(160 \mathrm{~mm} /$ week $)$ discontinued after summer season.

\section{Other effluents}

Effluent studies in other regions with dairy-shed wastes (Goold 1980) and meat works effluent (Russell 1986) indicate positive effects on pasture production and $\mathrm{N}$ removal.

\section{Safeguards}

Wastes can contain harmful elements such as heavy metals in sewage sludges or animal diseases in animal wastes. Heavy metals come from industrial sources and are therefore high in sewages from the larger cities like Auckland and Christchurch. Small towns generally have very low heavy metal contents in sewage (Quin 1979). Nevertheless, strict Health Department regulations are in place for the use of these materials (Collins 1984).

Likewise, with good husbandry practices, wastes from pigs, poultry and dairy cows should be free of major diseases, and if applied correctly with suitable withholding periods prior to grazing (allowing maximum exposure to sunlight) no health problems should occur. 


\section{Practical implications}

A knowledge of the nutrient content of various wastes plus the nutrient requirements formaximising pasture or crop production allows recommendations to be made on rates of application together with any solid fertiliser which might be required (Table 5).

\section{Dairy farms}

In general, effluents are ideally suited for application to pastures (Table 5). All contain nitrogen which gives a rapid response in the grasses. Generally they need to be supplemented with phosphorus and/or potassium to maintain maximum pasture production. The dilute nature of some of the effluents means that to be effective large quantities are needed (e.g. dairy shed effluent). Nevertheless they are a useful resource for farmers to utilise. Poultry manure is the major solid wastematerial forpasture topdressing containing good levels of nitrogen and phosphorus.

\section{Orchards, e.g. kiwifruit}

Orchards offer a good opportunity to utilise waste materials. Organic wastes, in particular, offer both a nutrient and a soil conditioning effect. Table 5 shows the nutrient contribution from poultry manure and compost applied at $7-10 \mathrm{t} /$ ha and sewage sludge applied at $5000 \mathrm{I} /$ ha (approximately $1 \mathrm{t} / \mathrm{ha}$ on a dry weight basis). Additions of organic wastes can also have very beneficial effects on the physical characteristics of soils leading to better soil waterholding capacity and possibly better conditions for root growth (Marsh \& Rixon 1991). This could have important implications for a permanent crop like kiwifruit subjected to the continued compacting effects of machinery.

\section{Cropping, e.g. maize}

Cropping land in the BOP is used mainly for maize growing. Maize will benefit from the addition of large quantities of nutrients (Table 5). This can be achieved by the addition of heavy quantities of organic waste (Table 5) worked into the topsoil. No further fertiliser additions would be required. Such additions of organic matter would be considered beneficial to soil physical conditions particularly where continuous cropping was practised.

\section{Special purpose effluent disposal}

Wastes such as sewage effluent are probably best applied to specific areas planted to special-purpose species such as tall fescue. Evidence suggests excellent

Table S Recommended waste applications' for dairy farms. orchards and crop land.

\begin{tabular}{lcc}
\hline Waste & $\begin{array}{c}\text { Application rate } \\
\text { (litres or tonnes/ha) }\end{array}$ & $\begin{array}{c}\text { Nutrients applied } \\
\text { (kg/ha) }\end{array}$ \\
\hline
\end{tabular}

(1) Dairy Farm

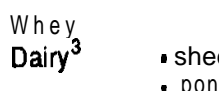

Pig slurry

Poultry manure

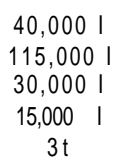

$3 t$

$\begin{array}{cl}7 \mathrm{t} & 105 \\ 5000 \mathrm{l1t} & 55 \\ 10 \mathrm{t} & 170\end{array}$

35
5
3
30
21

66

35

6

4

18
Nil

$350 \quad 15 \%$ K Super

$40030 \%$ K Super $150 \mathrm{KCl}$

$20050 \%$ K Super
(2) Orchard (e.g. KIwifruli)

Poultry manure
Sewage sludge
Compost'

(3) Crop land (e.g. maize)

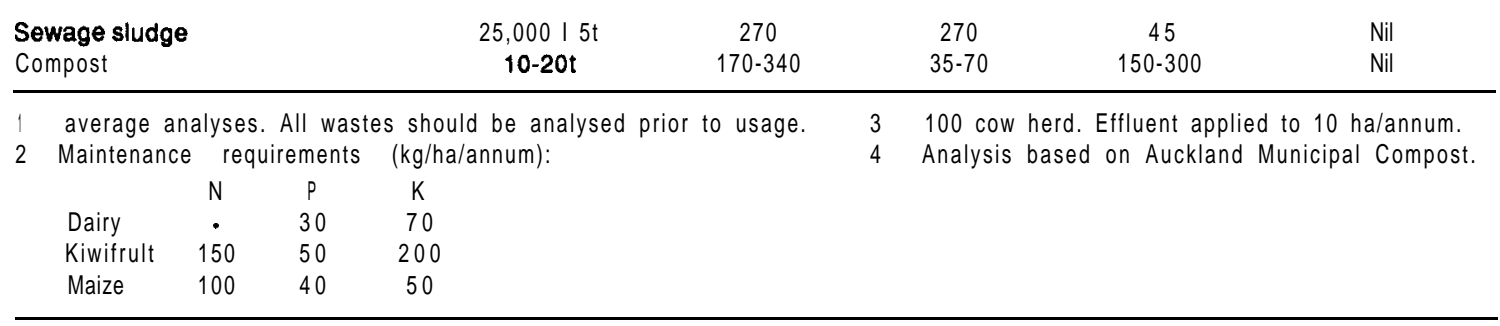


nutrient 'stripping' together with high levels of plant productivity can be achieved with relatively high application rates of effluent.

\section{Economic considerations}

In order to encourage widespread utilisation of wastes by farmers and orchardists. it will be necessary for New Zealand to adopt the principle of the waste producer paying for the safe disposal or utilisation of these materials. This principle has been adopted in many overseas countries. Where the waste producer carries the cost, the economic viability of waste utilisation becomes muchmore attractive. For particular waste materials (e.g. sewage sludge) a subsidy for its use may be appropriate In West Germany, for instance, farmers are paid $\$ 200 /$ ha to use sewage sludge on their land.

\section{Conclusions}

Numerous waste materials are produced in New Zealand which could be used effectively in agriculture and horticulture. Estimates for the Bay of Plenty region suggest a valuable resource, in excess of $\$ 7.5$ million annually, is available. Three factors are important for the successful utilisation of these materials:

1. applicationrates need to be balanced to the nutrient needs of the soil-plant system.

2. safeguards in the form of regular chemical analyses of the effluent, the soil, the plant, and the animal need to be present.

3. the economics of using the materials must be favourable to the farmer and orchardist.

\section{ACKNOWLEDGEMENTS}

The authors acknowledge the following for supplying data: B. S. Thorrold, T. Johnston (BOP Fertiliser Coy.), N.Z. Dairy Group (Reporoa), Tasman Pulp and Paper Company, Kawerau and FRI, Rotorua.

\section{REFERENCES}

Childs, C.W.; Searle, P.L.; Wells, L. 1977. Infiltration through soil as a tertiary treatment of sewage efluent. N.Z. journal of science 20: 433-7.

Collins, C.M. 1984. Disposal of sewage sludge on land. Memo 1984193. Department of Health, Wellington. $11 \mathrm{pp}$.

Goold, G.J. 1980. Rates of dairy shed effluent applied to pastures on day soils in Northland. N.Z. Journal of experimental agriculture 8: 93-9.

Marsh, J.D.M.; Rixon, A.J. 1991. Effects of heavy additions of organic residues on physical characteristics of three soil types in Queensland, Australia. Soil and tillage research 20: 109-122.

Mason, L. 1991. The road to tougher slurry legislation. Farmers Weekly, March 1991.

Meat\&Wool Board Economic Service, 1991. Fertiliser - is it worth it? N.Z. Meat Producer, 3.

O'Connor, M.B. 1979. Yield and chemical composition of luceme on a pumice soil as affected by regular application of secondary treated sewage effluent.

Progress in water technology 11 (6): 427-432.

O'Connor, M.B. 1981. Agricultural Research Division A nnual Report, 1980/8 1.

Quin, Bert F. 1979. Surface irrigation with sewage effluent in New Zealand - a case study. Progress in water technology 11 (4/5) 103-126.

Rotorua District Council, 1991. Rotorua effluent purification project. Souvenir handbook.

Russell, J.M. 1986. Irrigation of primary treated and anaerobically treatedmeat-processing wastes onto pasture: Iysimeter trials. Agricultural wastes 18: 257-268.

Stevenson, C.D.; Wilcock R.J. 1979. Changes in water quality during irrigation with treated sewage effluent of luceme plots on pumice soils. Progress in water technology I I (6) 41-426.

Stevenson, C.D.; Fellows, S.K. 1984. General design aspects of systems for land application of effluents. Land Treatment of Wastes: Proceedings of a Seminar, Hamilton. Water \& Soil Miscellaneous publication No. 70: 359-374.

Van Wyk, L. 1990. Wood residues, who buys the byproduct? NZ Forest Industries, June 1990.35-36. 